MedieKultur | Journal of media and communication research | ISSN 1901-9726

Article - Theme section

\title{
On political activism in digital games
}

\author{
Daniel Cermak-Sassenrath
}

MedieKultur 2018, 64, 87-115

Published by SMID | Society of Media researchers In Denmark | www.smid.dk

The online version of this text can be found open access at https://tidsskrift.dk/mediekultur

\begin{abstract}
This article investigates how players of digital games apply their own play with the intent to transmit political messages to other players. Acts of activism are collected from a sample of commercial multiplayer online games; three taxonomies are proposed of which one is used to present the findings, and popular patterns or structures of activism are identified. It is found that in-game activism often takes its cue from activism in everyday life, but that some original topics emerge, for example, the ownership of virtual worlds and practices of in-game political activism such as novel forms of rallies. Current political activism often appears to utilize generic and widely-shared game mechanics, rather than mechanics specific to individual games or genres. Games are therefore selected for their topics, availability, and costs, and popularity with the target audience.
\end{abstract}

\section{Introduction}

How do players play digital games with the intention to communicate their political conviction toward other players? This text investigates player-initiated forms of activism within mainstream digital games which target other players with political messages. It is 
expected to find many causes and themes which align tightly with political activism in everyday life, but also some original and possibly experimental forms of in-game activism native to digital play.

The investigation starts with the understanding that natural things and cultural artefacts are routinely appropriated, utilized, and subverted, not extraordinarily, but by everyday people for mundane use, which is a dynamic process driven more by individual, collective, and emergent needs than by planning and preference (cf. Hall's encoding/decoding model and Barthes' discussion of authorship). This perspective supports the expectation that players potentially use games of all genres as vehicles for political expression. No medium or act is taken to be unpolitical; in fact, Flanagan states that "as with other media, games carry beliefs within their representation systems and mechanics" (2009, p. 4). The investigation focuses on games which have not been strategically designed to carry political messages, but are appropriated and imbued with political meaning by players, while the study excludes the so-called political games.

The notion of politics is taken here to refer to a rather loose set of societal issues, such as personal lifestyle choices, animal rights, protecting the environment, justice, distribution of wealth, work conditions, power relationships, emancipation, franchise/participation in decision-making processes, campaigning for or against politicians or parties, and international relations.

First, the investigation method and site are described. A sample of commercial multiplayer online games is inspected, and (well-known and obscure) instances of activism are collected. Three taxonomies are proposed, of which one is employed to present the results. Finally, popular patterns or structures within in-game activism are identified.

\section{Investigation method and site}

The method employed here is an analysis of shared online videos including authors' descriptions, authors and viewers' comments, and descriptions of works on authors' web sites.

Because live and often disruptive (e.g., unexpected) performances in games are "ephemeral artifacts" (Poremba, 2003) and hard to systematically observe in person, the investigation uses online videos of the events. It appears that activists often record and share videos of their own performances, or that performances are recorded (e.g., coincidentally) by other players. YouTube is pragmatically selected (Hine, 2015, pp. 25f.) as a site for the investigation because it is a popular video sharing platform. ${ }^{1}$ The site is searched, starting with well-known works and keywords (such as "political riot" and a game title), and then, by following links, the videos are accessed as enthusiasts might access them.

For each search, YouTube is run in a clean environment, that is, in a restarted browser and in its own private window with no browsing or searching history, cookies, or temporary files, to avoid polluting the results, their order, or the recommended videos. 
The use of found data or archive data has certain properties and limitations. The material is, for instance, readily available and abundant, and the use of online materials avoids the producer having to tailor his/her response to the expectations (such as categories) of the researcher; however, it also entails limited access to making sense of it (Hine, 2015, pp. 159-163) and self-selected participation.

The videos are analyzed in an open process and categorized bottom-up. The descriptions given by authors are used to contextualize the videos; occasionally, viewer comments are observed to support or complement author descriptions. Usually, individuals who, e.g., left online comments, are not identified by name in this text and quotes are few and brief (Hine, 2015, p. 163).

The focus of this investigation is player-initiated political performances (or the enabling of such events, e.g., through mods) in popular digital games, which are targeted at other players. It includes a performance or event, or special gameplay if:

- A specific political opinion or message is explicitly formulated or clearly implied,

- It happens in-game, during play time, for instance, in a participatory (e.g., demonstration) or disruptive manner (i.e., hindering other players to play),

- It is created by players, not by game designers or publishers, ${ }^{2}$

- It is unsolicited, nobody asks players to act like this; the players do not merely fill-in the blanks designers have prepared ${ }^{3}$ (this includes some assumptions about what play was expected by the designers), and

- Video documentation of the event or artefact itself is publicly available and can be examined.

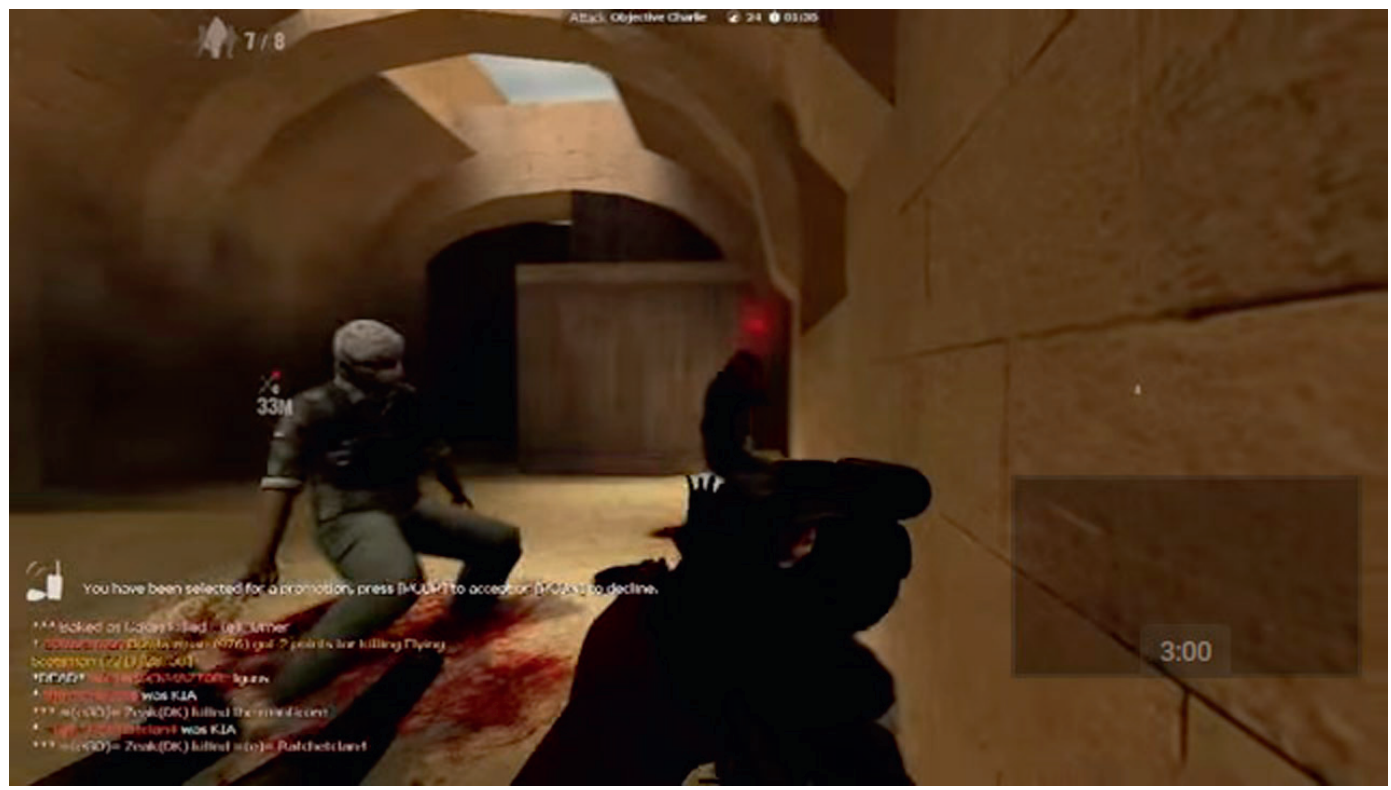

Figure 1. Insurgency mod for Half-Life 2 gameplay (InfestedChris, 2011). 
Thus, excluded from the investigation are (although all of these can be considered highly political acts or expressions) the following:

- Choosing to play or not to play a game, or (not) to play a specific role in a game (e.g., the fascists in Combat Mission [Dyer-Witheford \& de Peuter, 2009, p. 193]),

- Playing and making of political games, such as $1378(\mathrm{~km})$ (Stober, 2010), 1979 Revolution: Black Friday (iNK, 2016), Airport Security (Persuasive Games, 2006), America's Army (U.S. Army, 2002-), Antiwargame (Futurefarmers, 2001), Balance of Power (Mindscape, 1985), Campaign - General Election Edition (Anonymous, n.d.), Darfur is Dying (TAKE ACTION games, 2006), Escape from Woomera (Katharine Neil et al., publicly available prototype 2004, Figure 2), Faith Fighter (Molleindustria, 2008), Food Force (WFP, 2005), Global Conflicts: Palestine (Serious Games Interactive, 2007), Hush (Antonisse \& Johnson, 2007), Insurgency (New World Interactive, 2007, Figure 1), JFK Reloaded (Traffic Management Limited, 2004), Kabul Kaboom! (Frasca, 2001), Kill Box (DeLappe et al., ca. 2015), Kumal War (Kuma Reality Games, 2004), The McDonald's Game (Molleindustria, 2006), Oil God (Persuasive Games, n.d.), Oiligarchy (Molleindustria, 2008), Papers Please (3909, 2013), PeaceMaker (ImpactGames, 2007), Phone Story (Molleindustria, 2011), Plague Tetris (ca. 2012) and Slave Tetris (2013) mini-games (Serious Games Interactive' Playing History educational game series), Plan It Green, the Big Switch (CONNECT! Transform the Future, n.d.), Riot Simulator (RIOT, 2017), Seal Hunter (Toumaz, 2007, or earlier), September 12th (Gonzalo Frasca, 2003), Spec Ops: The Line (Yager Development, 2012), SPENT (Urban Ministries of Durham, 2011), Super Columbine Massacre RPG! (Ledonne, 2005), Under Ash (Afkar Media, 2001), Under Siege (Afkar Media, 2005), Vigilance 1.0 (Le Chevallier, 2001), and Waco Resurrection (C-level, 2003),

- Playing games which were probably not intended to be political, but to which political controversies became attached, such as Alpha Centauri (Electronic Arts, 1999), BioShock Infinite (2K Games, 2013), Civilisation (MPS Labs, 1991-), Colonisation (MicroProse, 1994), SimCity (Maxis et al., 1989-) and The Sims (Maxis, 2000-; The Sims itself is excluded from this investigation, but special plays of it are included),

- Employing political in-game advertising such as Obama 2008 U.S. presidential campaign posters in Guitar Hero 3, The Incredible Hulk (McElroy, 2008), Burnout Paradise, Skate 2, NASCAR 09, Madden NFL 09, NHL 09, NBA Live 09, and at least ten other games (Sinclair, 2008; commercial in-game advertising is quite common, but is here taken to not be political), and

- Machinima, using games as (e.g., visual) source material for political videos. Many machinimas with political tropes exist which use games such as WoW (Machinima, 2008), Team Fortress (RoxyPox, 2012), The Sims (TheSims2MovieGirl1, 2012), Minecraft (ChronosPallas, 2015), and Second Life (Nornsonur, 2012). 
Dyer-Witheford and de Peuter (2009, p. 186) report a machinima, The French Democracy, made with the game The Movies. The This Spartan Life talk show (Weird_Stealth, 2006) is made using Halo 2 (2004) and Halo 3 (2007).

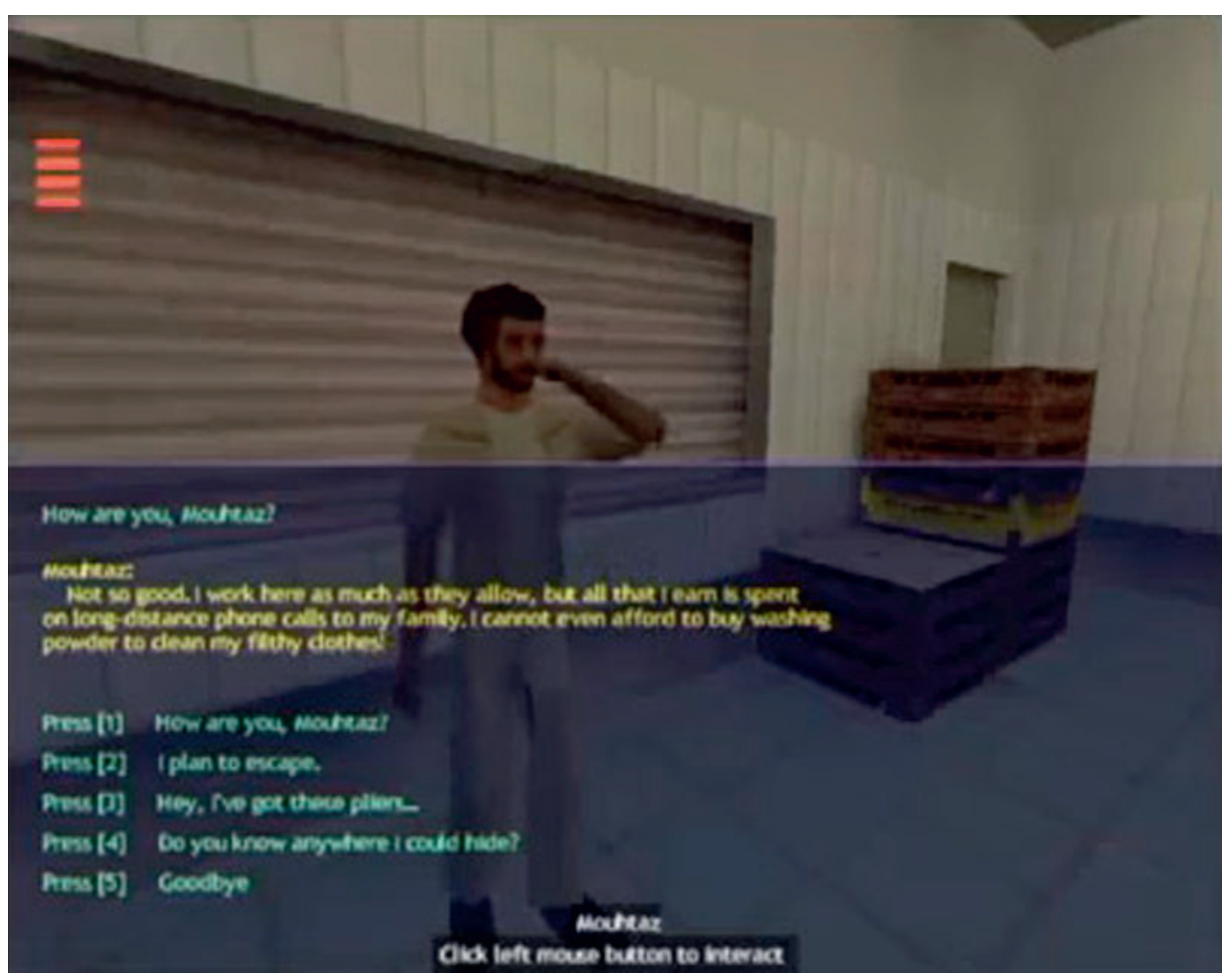

Figure 2. Escape from Woomera.

It is expected that certain games or genres are prominent among the games used for the subset of political activism defined above. The most relevant games for this investigation are persistent, massively multiplayer online games (MMOGs), such as World of Warcraft (WoW) (2004) and Second Life (2003), ${ }^{6}$ online first-person shooter (FPS) games, such as America's Army (many versions since 2002) and Counter-Strike (1999-), and, possibly, other networked games, such as racing games.

Well-known works and starting points for the investigation are political demonstrations and rallies in Second Life, DeLappe's dead-in-iraq performances in America's Army, Schleiner's Velvet-Strike mod for Counter-Strike, WoW pacifist guilds, and gender bending in WoW. There are many other potential starting points for such a project, for instance, Everquest (Taylor, 2006). 


\section{Results}

The sampling of a few hundred videos is not expected to provide a comprehensive list of acts of political activism in digital games; the events and performances are merely intended to identify messages, methods, mechanics, and, possibly, popular patterns and combinations of these. The results show a snapshot of observable acts and events; many of these have been extensively covered, from many perspectives; a literature review is not intended; also, this text does not focus on reach, impact, influence, or effectivity; several of the videos used have fewer than 100 views.

There are many possibilities to categorize political activism in games. For instance, Dyer-Witheford and de Peuter (2009, p. 191) propose six categories of digital "countergaming" (Galloway's term), that is, "playing against - and beyond - games of Empire" (Galloway, 2006, pp. 107-126) and "interweaving paths of social activity remaking ludic practices" (Dyer-Witheford \& de Peuter, 2009, p. 211):

[...] counterplay, or acts of contestation within and against the ideologies of individual
games of Empire; dissonant development, the emergence of critical content in a few main-
stream games; tactical games designed by activists to disseminate radical social critique;
polity simulators, associated with the educational and training projects of the "serious
games" movement; the self-organized worlds of players producing game content indepen-
dently of commercial studios, especially in MMOs; and [...] software commons challenging
restrictions on and monopoly control over game-related intellectual property. (ibid., p. 191)

Poremba (2003) observes how "player-authors [...] hack and alter game code and graphics, play in new and undetermined contexts, and occasionally cross over the divide to produce their own games." Boluk and LeMieux (2017) propose the appreciation various practices associated with games, such as playing, making, and subverting them, as an integrated meta-game.

Here, three taxonomies are proposed: One taxonomy based on dissemination method or strategy, one based on political message, and one based on game mechanics. Of these, the first is selected and used to present a number of examples of acts of activism; the two other taxonomies and their application are roughly sketched.

\section{Categorization by dissemination method}

One way to categorize in-game acts of activism is by the dissemination method. This categorization reflects that events differ in their participatory and disruptive qualities (that is, their effects on other players beyond the activist[s]). The following categories are roughly sorted, ranging from much participation and disruption to little. Based on the observations in the sample of games, five categories are identified: participatory or disruptive live performances; demonstrations, rallies, or celebrations; locations, objects, or imagery; text chat or team speak re-enactments; and challenges, runs, or special plays. 
The borders of these categories are somewhat fuzzy and debatable. Depending on the angle, a single event could feature in multiple categories, because events often are multidimensional (for example, avatar skinning connected to in-game performances). Within categories, the works which demonstrate the category most clearly are listed first.

\section{Live performances}

Political activism can be expressed through live performances. Examples are game mods which enable specific plays or disrupt default gameplay, curated live roleplaying experiences, in-game audio replays, sing-along events, stand-up performances, mock terror attacks, and avatar skinning and naming. However, hacking the technical infrastructure of online games to reach in-game goals breaks the frame of play. Contrary to prior expectations, observed were neither speeches, talks, lectures nor strikes. DeLappe's performances regularly include starting a game, but not actually playing it; however, this is taken to be a side effect of him focusing on using the communication channels of the game to broadcast political messages.

One well-known example for an in-game disruptive performance is Velvet-Strike by Schleiner, Condon, and Leandre (2002). Velvet-Strike is "a selection of protest tags for a Counter-Strike graffiti modification called Counterspray" (Poremba, 2003; Counter-Strike itself started as a mod for Half-Life before it became a stand-alone game); it "was created in response to the U.S. wars in Afghanistan and Iraq, specifically for the proliferation of militaristic anti-Arab, anti-Muslim Counter-Strike modifications following 9-11" (XYZ Exhibition, 2002; see opensorcery.net/aboutvs.html [Aug 21, 2017]). Velvet-Strike allows players to participate in live performative events: to spray paint peace-themed graffiti on walls and objects during matches, instead of fighting the opposing team, and to give each other virtual blowjobs (Dyer-Witheford \& de Peuter, 2009, p. 186). The game CounterStrike is selected for its violent gameplay and militaristic content (Counter-Strike by itself is not anti-Arab) and its presumed popularity among players.

A virtual live role playing experience is offered by Virtual Guantanamo (2007) in Second Life, run by the Interactive Media Division of USC's School of Cinematic Arts (Despres, 2007). The participant's avatar is deported to a virtually recreated Guantanamo Bay Detention Center and kept in a cage (ibid.) at Camp X-ray for a curated prison experience. Virtual Guantanamo informs people about the base's existence and the prison's conditions in a more immediate way than news reports (ibid.), and raises awareness of the fact that suspects are held in detention outside of the law by U.S. authorities.

A player of Tom Clancy's Rainbox Six: Rogue Spear uses an in-game audio replay to express his political conviction and to annoy other players. He skins his avatar with "a Swastika arm patch" (rabidns, 2005) and configures the game so "every time he kills someone [...] the Horst Wessel [song]" is played in-game (ibid.). The political expression is unspecifically pro-Nazi. It is realized by (weakly) connecting the in-game audio playback 
of a political song with game actions. The performance is similar to Velvet-Strike, but it augments (and does not stop) gameplay with a politically controversial and potentially disruptive expression: He reports "the bad reaction [he] would get from all the liberal, Linkin Park loving brats" (ibid.).

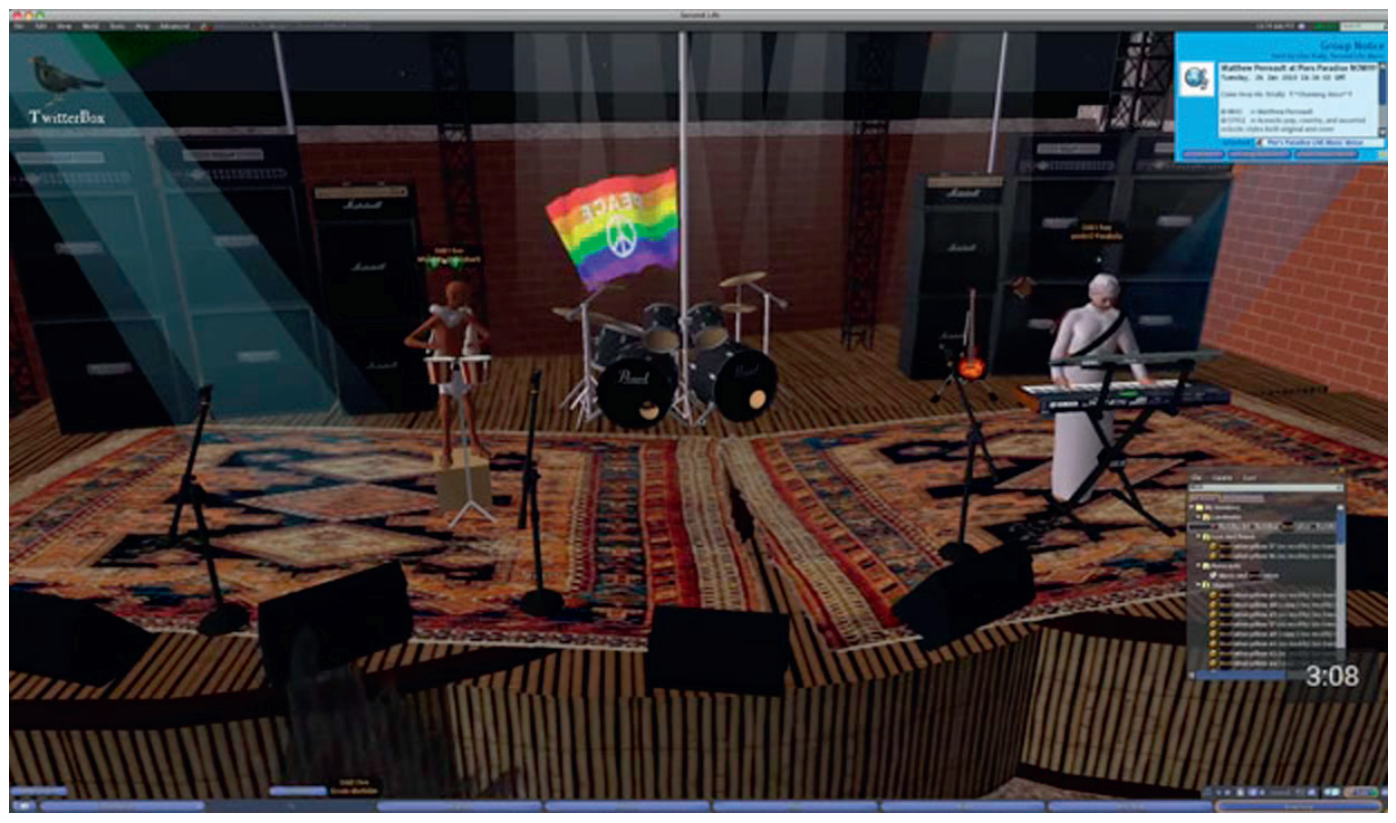

Figure 3. gg hootenanny performance in Second Life.

A participatory sing-along event was staged by DeLappe in Second Life. He describes the day-long gg hootenanny! festival (DeLappe, 2010a, Figure 3) as the "first ever internetwide global gaming voicechat singalong" (ibid.). He invited participants to sing with his Gandhi-esque avatar and to play instruments, the live audio "being transmitted via voice chat" (DeLappe, 2010b) not only in Second Life but also in people's "favorite game online" (DeLappe, 2010a, 1'20). Judging from the choice of persona, the stage decoration, and the "songs of freedom and protest" (ibid.), the promotion of world peace is the political message. The in-game event was an on-stage performance held on the anniversary of Gandhi's actual release from prison in 1930 (DeLappe, 2017c); however, from the in-game audio, it appears that few people participated.

A satirical anti-Trump stand-up performance in Second Life was staged during the 2016 U.S. presidential election campaign (Cleptar, 2016, Figure 4). A character with a "Make America Great Again" sign sits on a fence and addresses random passers-by ("Hey man, do you vote for Trump?" [4'42]), outlines Trump's qualities ("He's got a big penis" [1'14]), argues, insults ("This is America, you speak English. [...] Get out of my country." [5'20]), and makes claims ("Trump is the greatest man on this God-given planet." [4'03], "A vote for 


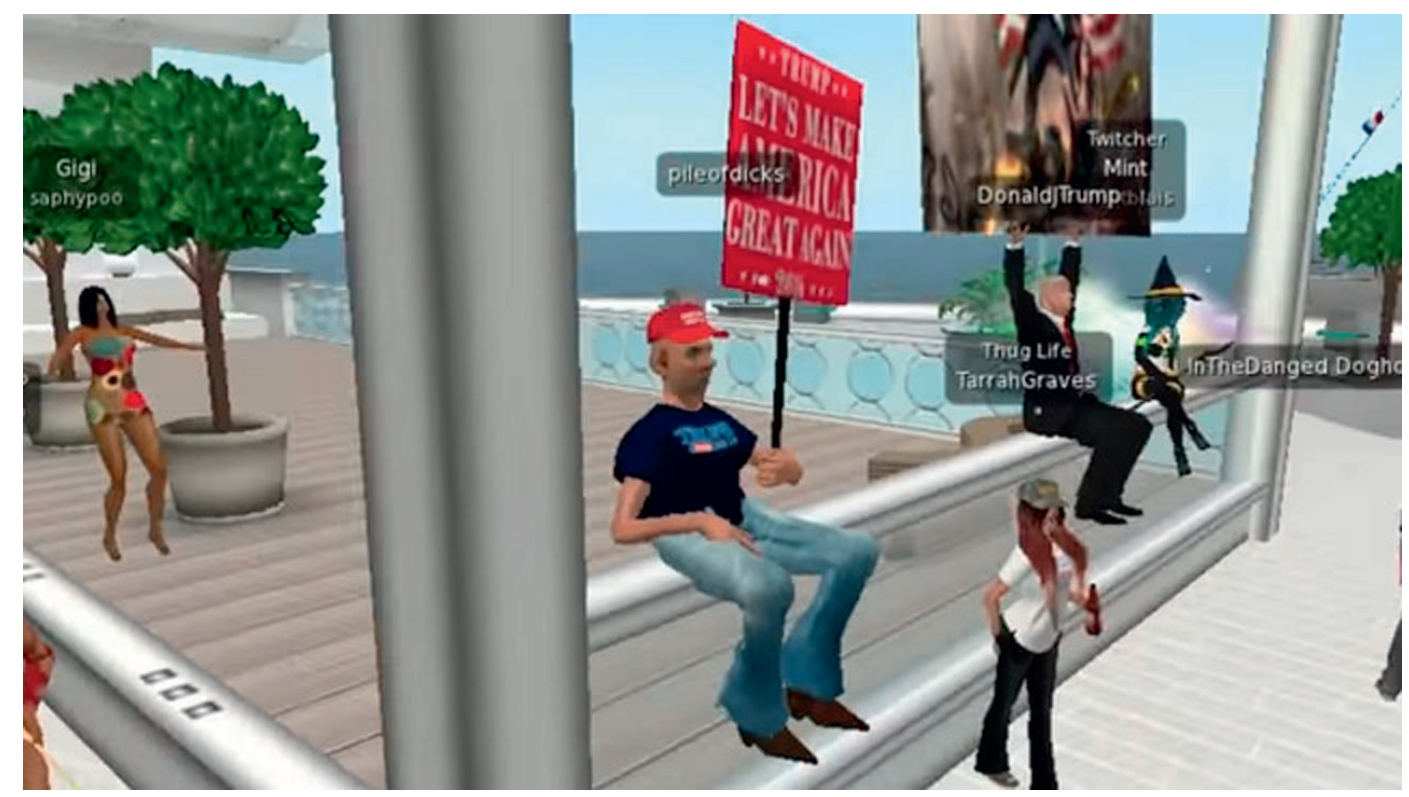

Figure 4. Trump satire performance in Second Life.

Trump is a vote for God." [4'12], and "Clinton is a dumb one." [9'20]). The event uses solely live audio, with no text typing. Controversial exchanges occur. Apparently, as a sign of disagreement, the area is showered with hamburgers by somebody (2'50).

Live performances in games can also take the form of mock terror attacks. Two examples are an anti-fur performance (ediblefeet, 2006) and a "Hippo Terror Attack" (cartmantul, 2009a, Figure 5), both in Second Life. Both appear to play off the real-life terror threat by organized groups with weapons against civilians, but actually only employ in-game avatars, objects, and actions for show, rather than to effect action.

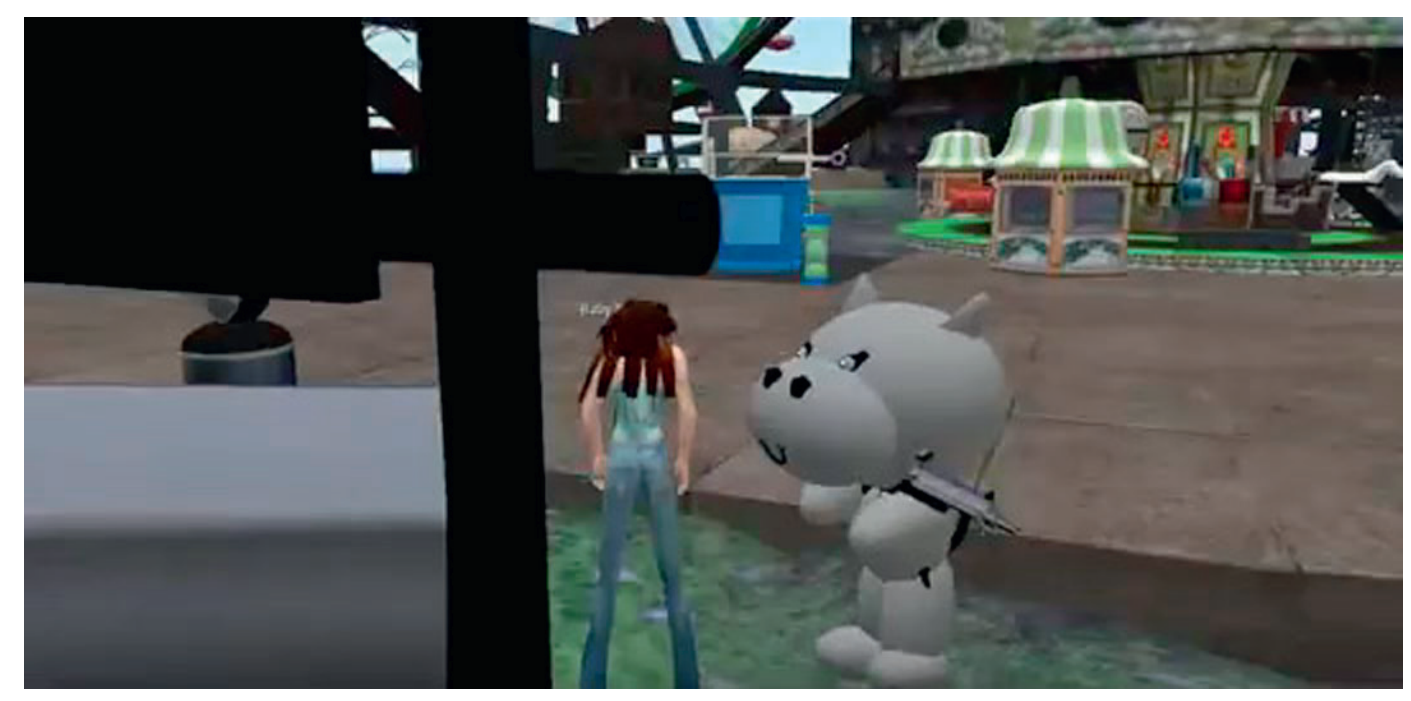

Figure 5. Almost a hippo terrorist attack in Second Life? 
An example of avatar skinning is demonstrated by DeLappe with his Self Portrait as Monster Truck (2011). The work is a video of a Second Life avatar which is "clothed entirely in multiple copies of a monster truck walking through the sky" (DeLappe, 2011; see also DeLappe, 2017a). It is an absurd display of the skinning mechanic and appears to highlight the sometimes intimate relationships among people, their bodies, and their vehicles; it is unclear if or how visible the performance is in-game to other players. There is no interaction with other players shown in the video.

In the 1990s, female gamers created specifically female skins and avatars for violent games (Dyer-Witheford \& de Peuter, 2009, p. 21) and made them available to other players as a reaction to the dominance of the stereotype of the young male digital gamer. Following the 9/11 terror attack in 2001, in-game skins for "Osama bin Laden, Saddam Hussein, and even 'Chemical Ali' and other terrorist and military skins [...] began to appear in games as diverse as Quake, Unreal [...] and The Sims" (Poremba, 2003). The naming of in-game avatars is a practice similar to skinning.

\section{Demonstrations, rallies, or celebrations}

Political activism in games can take the form of demonstrations, rallies, or celebrations. Participants exhibit the standard behaviors, such as occupying a location (standing, sitting, walking, or sailing); showing signs with political slogans, images and symbols; shouting or chanting (text or voice chat, or pre-recorded audio); and addressing passers-by and counter-demonstrators and discussing with them. Rarely do participants carry weaponlike objects, such as power saws, and, when they do, it is for visual and auditory effect only. Occasionally, the events happen in time-parallel with events in everyday life (such as a war), or at the same (virtually re-created) locations. Sometimes, an event does not happen at a single location, but is organized as a march from one point to another, along a certain route.

The events are participatory and voluntary, and they can be disruptive. Their actual impact on other players is marginal and rather symbolic; no damage is usually done to avatars, property, or infrastructure. Moods within and between events range from very serious to barely serious. In-game blockades are rare. Political flash mobs or turf wars could not be observed.

A rally can support a politician such as Ron Paul, a candidate in the U.S. Republican primaries in 2008. The WoW guild RP Revolution organized a rally in Whisperwind (zero696696, 2008; see also xxyxs, 2008). Participants line up, run to the meeting place, totally fill it up (Figure 6), and chat with each other. A similar event, several years later, again organized by RP Revolution, is RON PAUL'S WORLD OF WARCRAFT MARCH TO FREEDOM. About 300 participants (PISTOLcm, 2013) meet, and then together traverse various areas of the game world, including sailing from the Eastern Kingdoms to Kalimdor. 
Article: On political activism in digital games

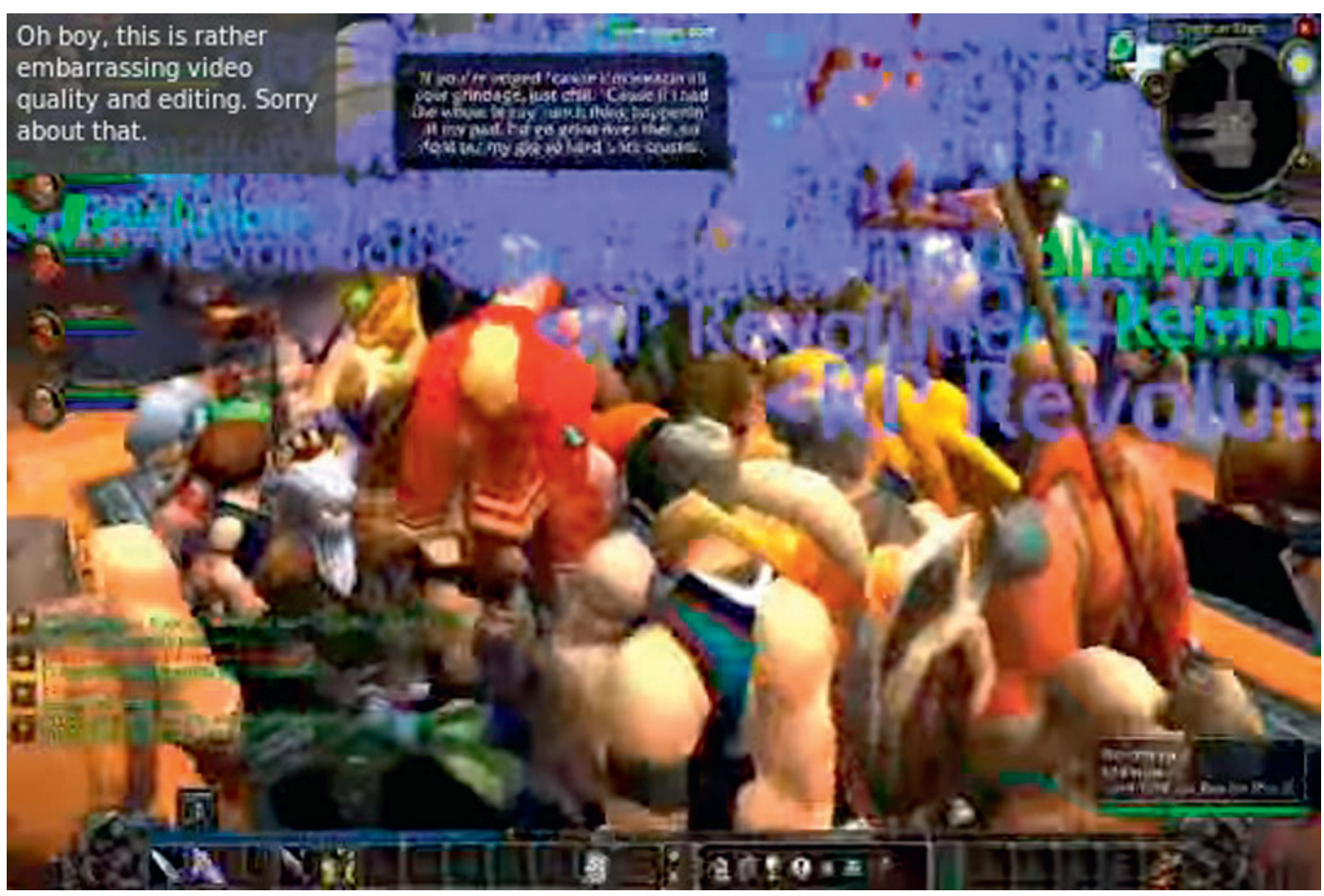

Figure 6. WoW rally for Ron Paul.

A specific kind of the political rally is the protest rally. Protest rallies in Second Life are directed, for example, against U.S. president Trump (Kotaku, 2016), the French Front National (ediblefeet, 2007), Egyptian president Mubarak (Panganiban, 2011a), and the 2008-2009 Gaza War (idccom, 2008). 
Article: On political activism in digital games

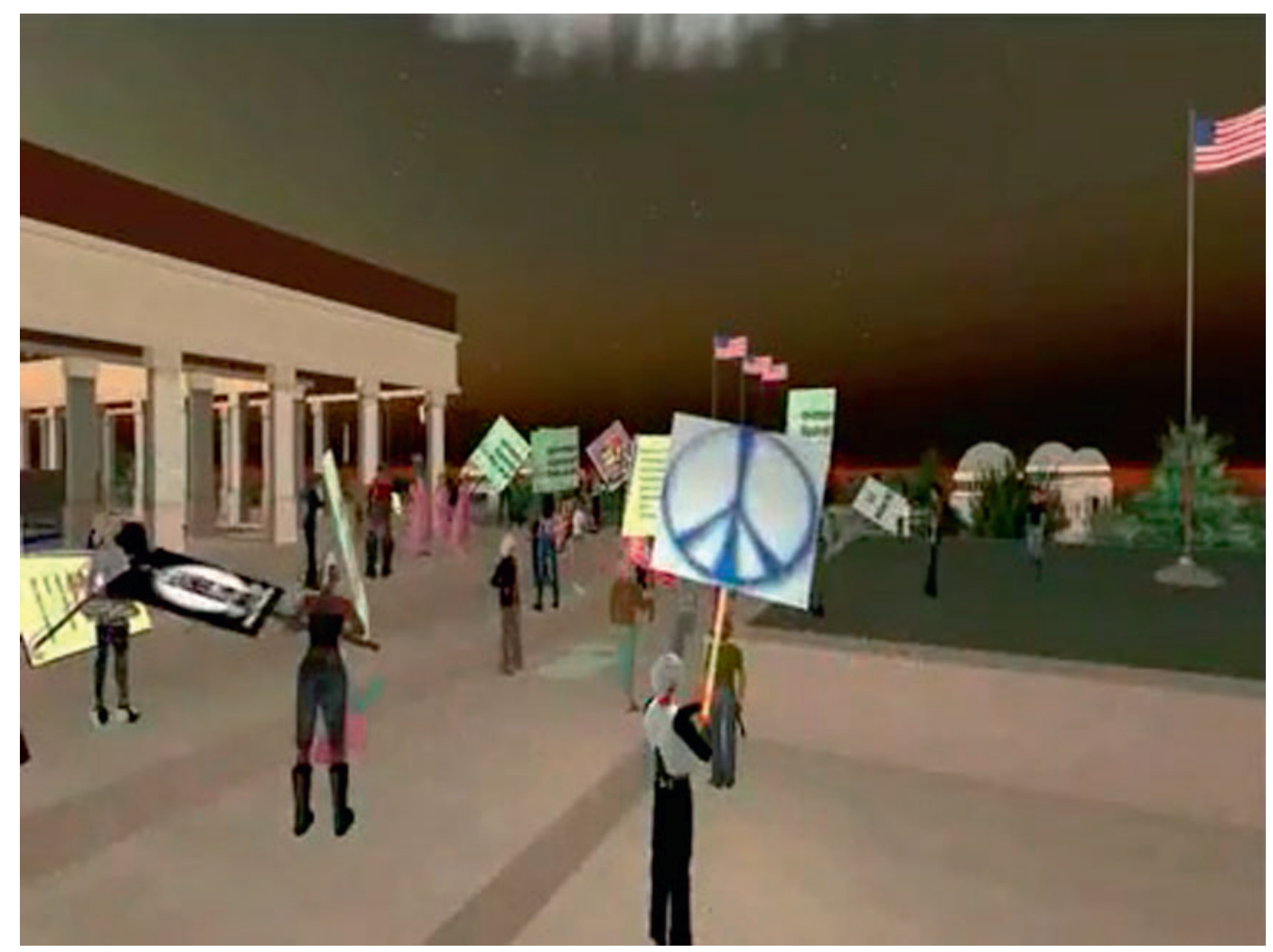

Figure 7. Avatars Against War demonstration in Second Life.

A peace demo, as known from everyday life, is another kind of rally, usually directed against military conflict, violence, and/or arms build-up (e.g., Panganiban, 2011b, Figure 7). 


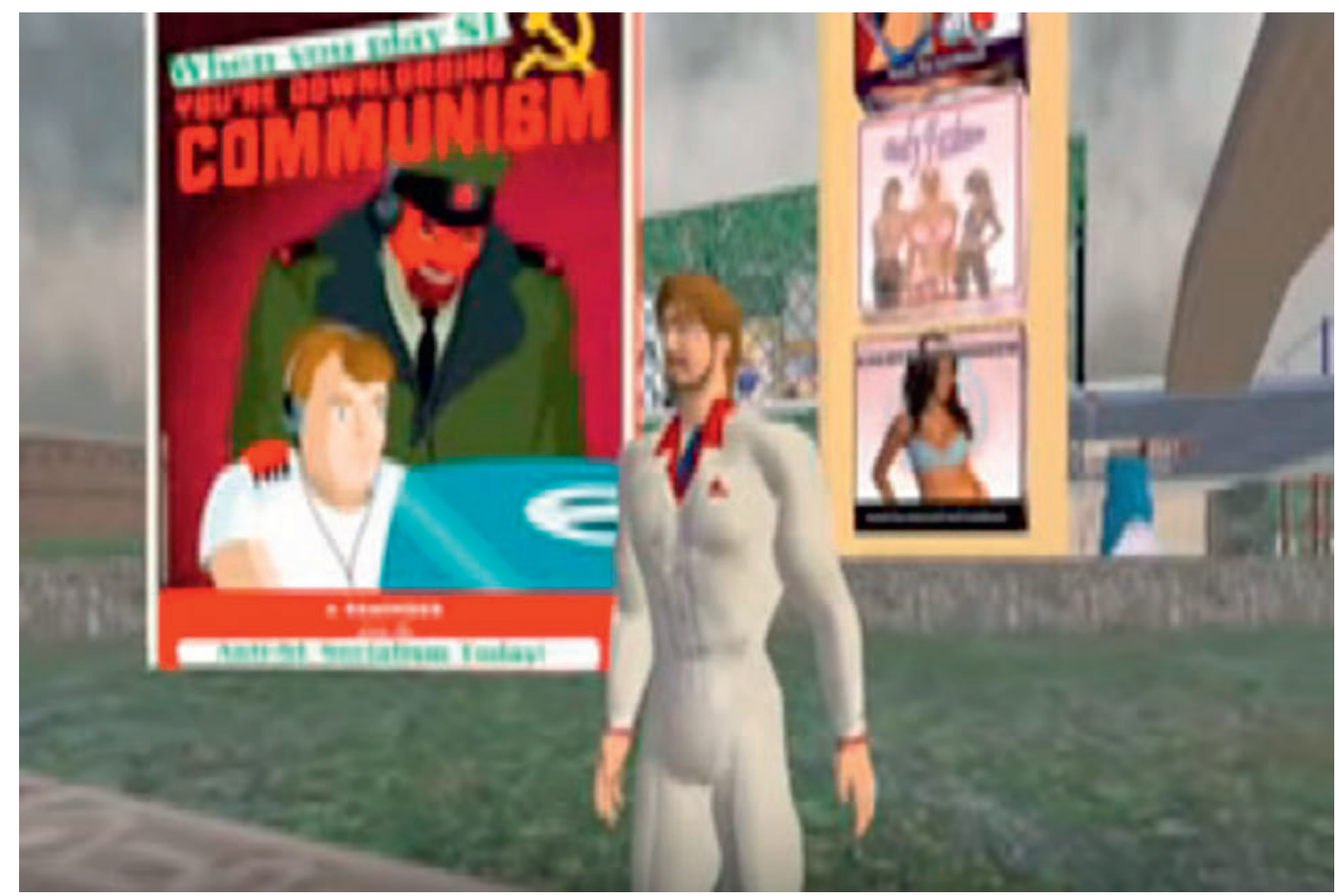

Figure 8. Anti-gambling ban demonstration in Second Life.

A topic which sparks protest rallies is the little control residents of online worlds are granted over their in-game rules and policies by the companies running them. For instance, in Second Life, rallies protest lax access regulations (piercep, 2006), a gambling ban (mattr0x, 2007, Figure 8) and increased open sim charges (White, 2008). 
Article: On political activism in digital games

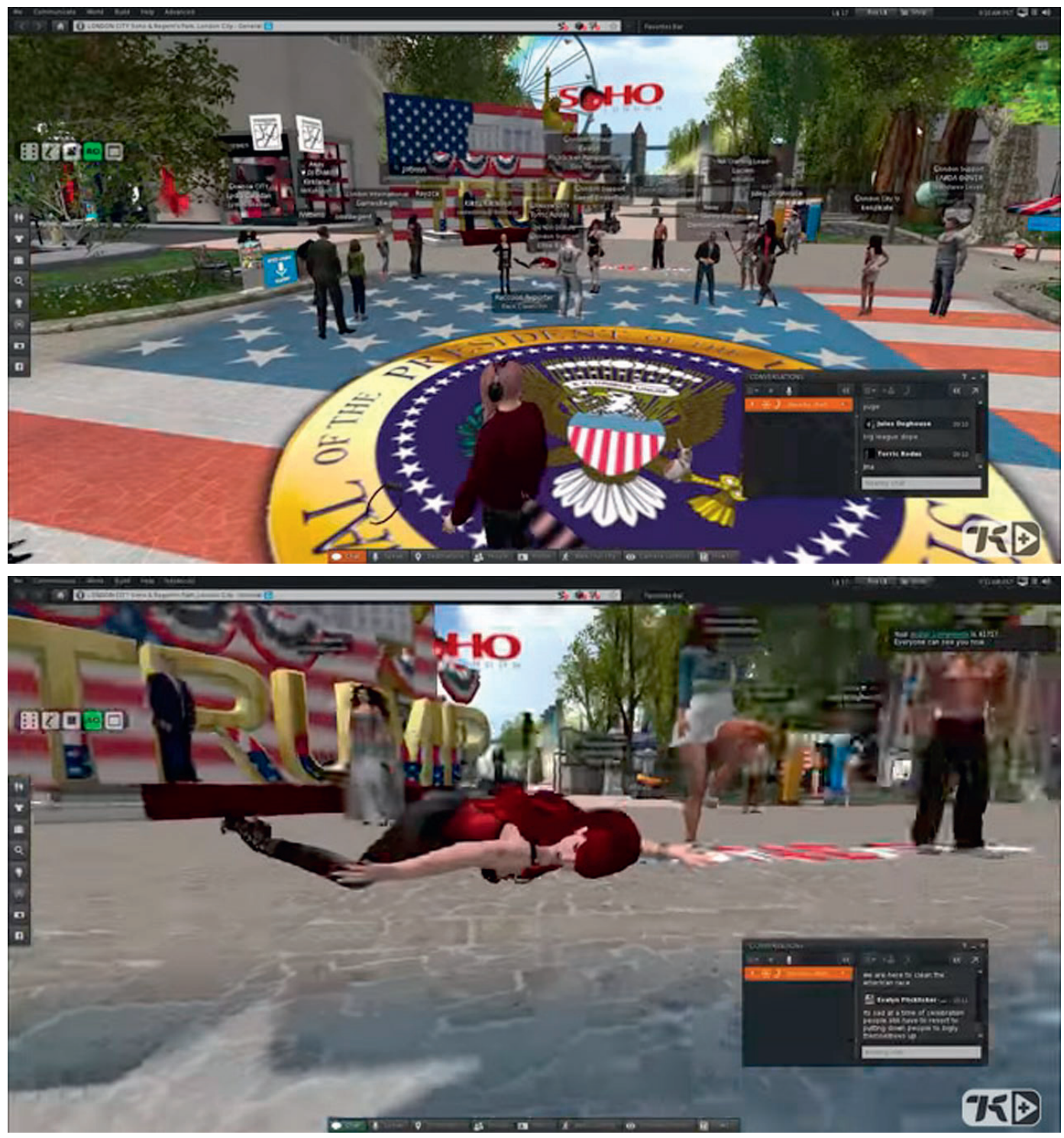

Figure 9. Trump Inauguration party in Second Life.

A public celebration of Trump's 2017 inauguration as U.S. president is portrayed in Second Life. The event is time-parallel and uses imagery from ordinary life, such as a display stand, large flag, and state seal (Figure 9, upper). People attend by standing and watching and possibly chatting with each other. The in-game event is described as "much more colorful" than the official event (Kotaku, 2017); one person shows that she is not enthusiastic by posing dead on the floor (Figure 9, lower).

In persistent, competitive, and collaborative MMOGs, players often associate in in-game organizations. Many female gaming groups emerged in the late 1990s in "hypermasculinized competitive games, like Quake, where [their] players often played 
against teams of all male competitors" (Richard \& Hoadley, 2013, p. 262). Dyer-Witheford and de Peuter (2009, p. 21) describe female "game clans such as PMS (Psycho Men Slayers) [and] Babes with an Attitude." The play of these groups of popular games "involv[es] exploration, competition and aggressive play, as much as social play" (Richard \& Hoadley, 2013, p. 262), probably with a bit a transvestism "thrown in" (Dyer-Witheford \& de Peuter, 2009, p. 21).

In WoW, such in-game organizations are called guilds. Usually, guilds serve players, among other things, to exchange help, advice, items, and services, to introduce new players to the game, and to organize raids. Many different guilds exist, some of which focus on gameplay, others on socializing. Some guilds are also politically-oriented. For instance, Endo is reportedly leftist (Zerxes, 2012). A forum member of Stormfront Canada starts a thread "World of Warcraft white nationalist guild" to find other WoW players "interested in joining a white nationalist guild" (ADLmostwanted, 2007). In a different thread, two members had already expressed their willingness to "START A BNP [British National Party] or National Alliance Guild somewhere" (badash, 2005) or to "play in a White Nationalist-only guild" (Corentin, 2005). There are at least two guilds named in one of the popular lists of WoW guilds which call themselves fascist. But, both the "Fascist Pigs" and the "Fascist Duelists" appear to be relatively inactive (WoWProgress.com, 2017a, 2017b), and information on the specific type of their fascism seems to be unavailable. Anders Breivik has played several WoW characters (Zakalwe, 2011), and was a member of several guilds (Virtue, Unit, Nordrassil, Nevermore) and the leader of some of them (ibid.).

WoW appears to feature some (rather simple, possibly) mechanisms to prevent reallife politics from intruding noticeably into the game world. In fact, another member of Stormfront Canada complains that he got banned for using the n-word in-game (BootsandBracers, 2007); in a different thread, a forum member reports in a post that politically-sensitive avatar names are also forbidden in the game (White Youth, 2005; an investigation of policies or in-game mechanisms to prevent (or invite) political expression is beyond the scope of this article). 


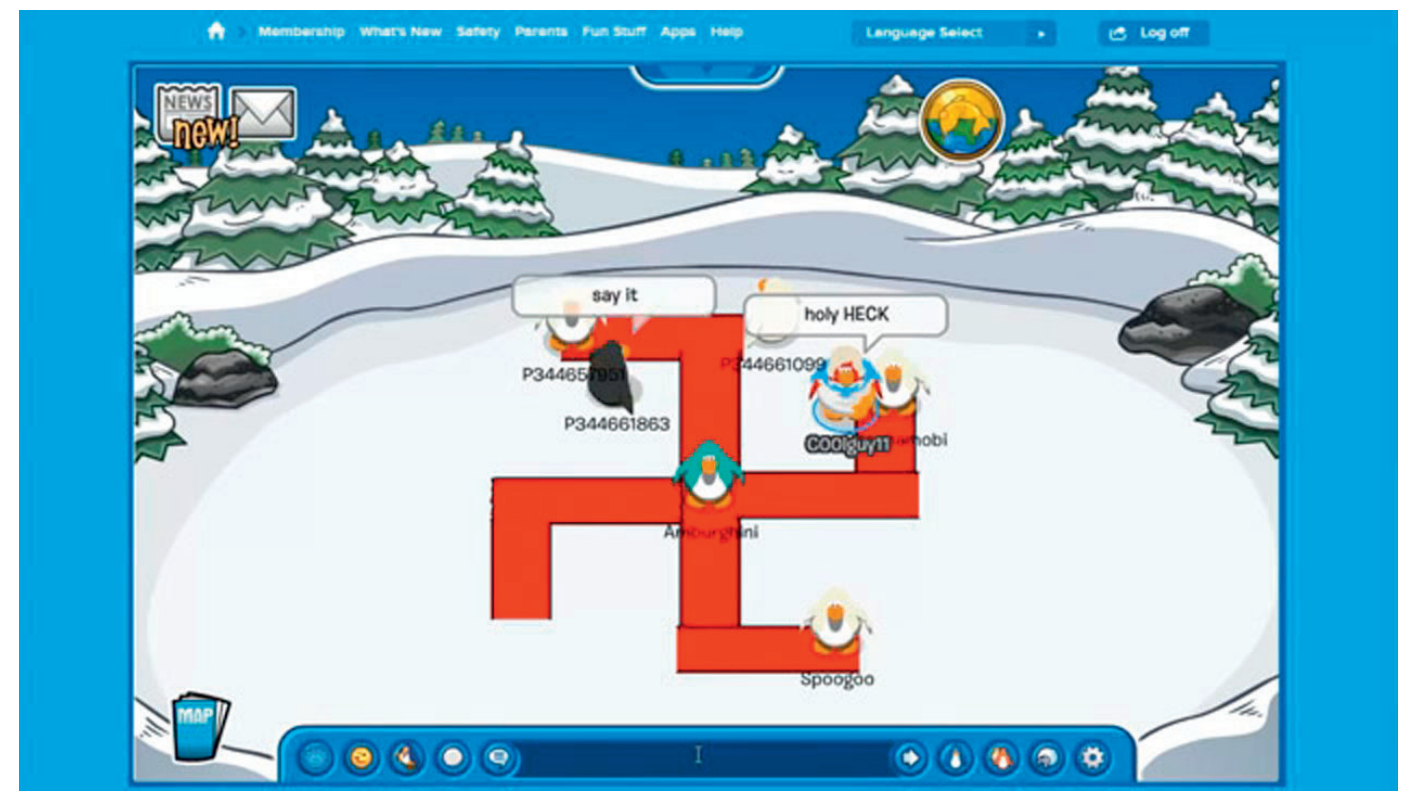

Figure 10. Swastika in Club Penguin.

Political conviction can be expressed through the live creation of symbols. When a game, such as the very restrictive Club Penguin which is "specifically designed for children aged 6 to 14" (Wikipedia, 2017), does not offer the import of graphics and the skinning of avatars or in-game objects, players can ingeniously work around these limitations and create symbols by the shared live performance of activists (Emillie, 2016, Figure 10) or by programmable bots (PCLScripters, 2008). The showing of the symbol is an in-game display only; no interaction with other players is observed or reported. The concrete political message is unclear, and might include a protest against the imminent platform shut down, its strict rules, and a real-life fascist position.

\section{Locations, objects, or imagery}

The creation and sharing of in-game locations and items can be an act of political activism. Such artefacts might mimic existing locations or objects in real life, and exhibit similar dimensions, proportions, colors, and surface textures; they might also be named similarly. Often, they feature slogans, symbols, photos, and videos. Usually, there is no live performance of the activist associated with such locations and objects.

Examples of politically-charged in-game locations are a location to mourn a protester killed in a riot in Greece (GiaNtakos, 2008) and a Trump p(a)lace in Second Life (TiffyKishman, unknown).

Image flashing is a straight-forward way of in-game political activism. Examples are a large billboard in support of the British Labour Party in Minecraft (ComradeMikey, 2017), 
decorative art in The Sims (Poremba, 2003), and the showering of an area in Second Life with a Nazi symbol (cartmantul, 2009b).

\section{Text chat or team speak re-enactments}

In-game communication channels, such as text chat (typing) and team speak (audio), in popular multiplayer online games can be appropriated to broadcast out-of-context political messages. DeLappe has popularized the uni-directional transmission of messages such as poems, plays, and lists of killed soldiers, which do not include any further interaction with other players. In such disruptive performances, his own gameplay stops, and his team's performance is likely to suffer, as well as the play experience of other players.

One in-game communication channel which can be appropriated is the text chat. Examples include DeLappe's recitation of Alan Ginsberg's poem “Howl' in Star Trek: Voyager - Elite Force in 2001 (DeLappe, 2001; see DeLappe, 2017b), his well-known deadin-iraq performances in America's Army 2006-2011 (DeLappe, 2007), and his three-part Great Debates performance in Battlefield Vietnam, Star Wars Jedi Knight Outcast, and The Sims Online, in 2004 (DeLappe, 2017d).

A performance which uses both, text chat and team speak is DeLappe's Quake Friends performance (2002) in Quake III Arena. Similar to the interventions above, an existing script is recited in a competitive and violent online game by several actors in-character (DeLappe, 2012; see also DeLappe, 2017e). Here, however, the material is not only typed-in, but also spoken out loud, using the game's team speak feature (ibid.).

\section{Challenges, runs, or special plays}

Specific ways to play games can function as a venue for political activism. In such plays, players usually still progress the game, but only make use of a subset of the options available in it, or aim for a result which goes beyond standard winning conditions or intends a different result. If players encounter in-game situations which are incompatible with their chosen style of playing, they either stop playing, or they temporarily suspend or permanently alter their own rules of play (e.g., by excluding certain types of enemies, such as level bosses, from their pacifist approach). Sometimes, game mods are allowed or disallowed.

There exists quite a range of specific plays and, within that range, many different opinions and inconsistent conventions of what specifically constitutes a special play (see, e.g., wowchallenges.com). Virtually all games are played in special ways and sometimes in absurd combinations (e.g., pacifist runs of violent FPS games). 
Players engage in special plays offline, record them, and share the videos online, or stream them in real-time, and they may even react to viewer comments. In many cases, it is debatable how visible a special play is in-game to other players. In games such as WoW, special plays are arguably visible to other players. Plays of offline and single-player games are often recorded and shared afterward, or streamed online; these are not visible at playing time to other players. Judging from the context in which the online videos are posted (e.g., the authors' descriptions and viewers' comments), it appears that it is often a competitive challenge, rather than a political cause, which motivates players to undertake (and share or stream) special plays.

Pacifist plays are very popular as special challenges in digital games. There exist a large number of videos of "pacifist runs" in many games. A pacifist run may mean no violence at all, no killing, killing only when unavoidable to progress the game, only killing of specific groups of enemies, no killing by the player avatar but by computer-controlled team members, no killing by the player avatar but by non-player characters (NPCs) under the player's influence, killing only by specific means, or only defending oneself when attacked. Many runs are offline or assumed to be offline and, thus, are not visible to other players during gameplay.

Speed runs are also popular with many players in many games. Games in which players perform speed runs include Dark Souls 3 (theDeModcracy, 2016) and The Legend of Zelda: Breath of the Wild (gymnast86, 2017).

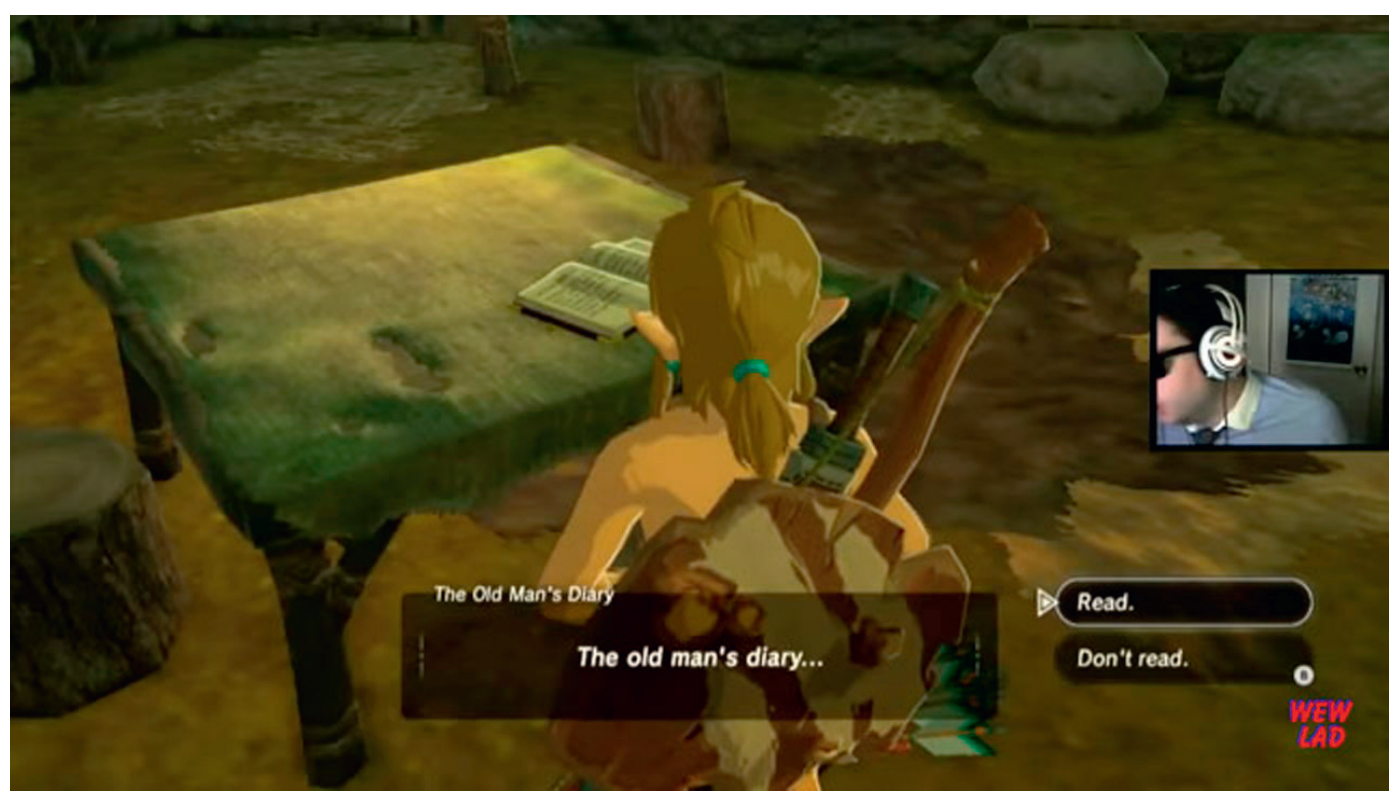

Figure 11. The Legend of Zelda - Breath of the Wild vegan run. 
Vegan plays are another variant of special plays. For example, one player performs a "100\% Naked and Vegan run" in The Legend of Zelda: Breath of the Wild (Figure 11) in which "[n]o armor or meat [is] allowed" (wew lad, 2017), for a "hippie-style" play-through (1'23). The play is streamed live. Two other players play the same game and set out to "put [...] Nintendo's statement to the test about being able to play the game without hunting or eating meat" (Weebhut Jr, 2017). They aim to do "a vegan play-through" in which they "are not killing any animals [...] [unless] [they] have to" (0'56). But a "boss is different" (1'07), and also excluded are "sentient rock creatures" (1'08). The players "are trying not to ride horses too" (1'13) because "that's not vegan" (1'19). But, they readily collect its jelly after killing a chuchu which attacks the protagonist Link ( $\left.8^{\prime} 08\right)$, which does not fall in the vegan category because it attacked (8'27).

Gender bending is a practice in digital games which can be connected to political convictions or causes, and can be performed as activism (excluded from the sample are instances of players playing an avatar of a different gender than their own when this does not result in in-game activism). Several mainstream games include cross-dressing as an in-game event and part of default gameplay. For instance, in Final Fantasy 7, the protagonist Cloud masquerades in a silk dress as a woman to be able to enter Don Corneo's house and interrogate him (BCSBuster, 2013). In Dark Souls 2, a gender change occurs (Cool Gaming, Bros, 2015). The male protagonist in Fable 2 is turned into a female by drinking a magic potion (Swarm TV, 2013). In WoW, players can celebrate Valentine's Day by embarking on special love-themed missions (Lees, 2006) and by wearing perfume which makes the avatar "appealing to male NPCs" or "cologne [which] makes female NPCs swoon at the sight of [the player's avatar], regardless of [his/her] actual gender" (ibid.). Some niche games also play with gender. Gender Bender DNA Twister Extreme is a game whose gameplay is built on gender switches (store.steampowered.com/app/321060; see e.g., knightgraymon, 2014).

Unsolicited gender bending occurs in many mainstream games, through playing styles, mods, tools, or cheat codes. In Fallout 4, the protagonist's gender can be changed both in-game, through plastic surgery in Diamond City, and through cheat codes (McGamer, 2015). The Lion's Pride Inn in Goldshire is notorious for erotic role-play (ERP) in the roleplaying (RP) variant of WoW, much of which consists of straight male players playing male avatars interacting with mostly "gay or bisexual" male players playing female avatars (Thompson, 2014, p. 4). Skincraft is a tool which players can use to modify their avatars' appearance in Minecraft (Csskitty, 2015). For The Sims 3, a tool is available to change a sim's gender, including various items of clothing (Smith, 2014; see Sundén and Sveningsson (2013) for an ethnographic investigation of queer play styles in an LGBT WoW guild, and Shaw (2014) on gender and identity politics in mainstream digital games). 


\section{Categorization by political message}

There exist many different political causes which trigger in-game activism. From the sample presented here, three groups of causes can be identified: real-life political positions, lifestyle choices, and in-game practices.

Real-life political positions include military conflict and national party politics; activists also attempt to educate players about political situations.

A very prominent topic which is referenced in many events is real-life war. Protests are mounted, for instance, against the Iraq War and the Gaza War. One game mod (VelvetStrike) protests "militaristic anti-Arab, anti-Muslim" game mods. DeLappe's dead-in-iraq performances are intended as a "memorial to those military personnel who have been killed" in Iraq and "as a cautionary gesture." Other works are made from more general pacifist, anti-violence, anti-military positions and promote world peace.

Support or rejection of specific everyday life political positions is also expressed. For instance, activists speak out for or against positions in national (e.g., British and French) party politics and individual politicians, such as Ron Paul, Donald Trump, and Hosni Mubarak. Sometimes, players aim to play in in-game organizations with specific political orientations, such as leftist or white nationalist groups. The support shown for Nazi, fascist, or right-wing positions often appears to be unspecific. Rarely, in-game artefacts are intended to serve as monuments to protesters killed in political riots. Some works aim to educate players or raise awareness of a political situation, such as Virtual Guantanamo, which informs people about the U.S. base's existence and the prison's conditions.?

Lifestyle choices which are reflected in in-game political activism include animal rights (wearing fur), nutrition (vegan), and sexual orientation (gay).

Two areas of activism can be identified which exclusively refer to in-game practices. One is works which protest and aim to overcome game violence; the other is works which protest rules and policies (such as top-down corporate control without residents' participation in Second Life). Activists might also protest against the imminent shut down of a platform, such as Club Penguin.

\section{Categorization by game mechanics}

The notion of game mechanics is taken here to refer to what happens in a game, how the game can be played, what is possible for players to do, and the reactions of the game. Game mechanics define sets of combinations of actions and consequences. The game mechanics employed for the dissemination of political messages can be divided into three categories. One set of mechanics touches on games' meta-specs and policies, another on appropriation features, and the third on gameplay features.

The notion of meta-specs refers to properties of the game, rather than events within the game. The meta-specs of a game highly relevant to political activism include networked (rather than local) multiplayer play, support of modding (e.g., games which can 
be modified by scripting, and the provision of tools and documentation by the developer), and persistent game worlds which enable shared, spontaneous, and live events. For instance, Carmack "isolat[es] [...] the core game engine [in Doom], making it easier to add new sound, graphic and level elements" (Poremba, 2003); Poremba (ibid.) interprets this as a primary author's "attempt to distance the primary work from the expression of [his] own agency" and "to assist further secondary production." Usually, activism selects game titles which offer gameplay and game content related to the political message (e.g., violent and militaristic FPS games).

Two policies which encourage political expression in games are the ability of players to associate with each other in player-controlled organizations and to have free and uncensored in-game communications (not limited, as in Club Penguin, or controlled, as in, to a much lesser degree, WoW).

Features which allow for the political appropriation of games by their players include the availability of a large (and varied) range of in-game locations and objects; the possibility for players to create and share content (such as items and locations); the import of real-life media (such as photos and videos) into the game; the skinning and animation of objects; in-game audio replays which can be connected to game actions (such as killing an enemy); and the scripting of objects and the ability to program bots (as in Club Penguin). Features of appropriation which specifically relate to the players' avatars include the players' possibilities to create avatars from a large range of options with regard to capabilities and appearances, or at least to choose which avatars to play (including their gender and the possibility to change it during the game) ${ }^{8}$ and to influence in their development (e.g., when levelling up); the skinning, naming, and dressing of avatars; and the recording and re-playing of avatar poses and movements.

Gameplay features relate to the availability of meaningful choices of in-game actions and playing strategies. The features connected to political expression in games include the free use of building blocks (as in Minecraft), drawing, tagging, or spray painting; the in-game presence of game developers or publishers (as in Second Life); the choice of various interactions between avatars (beyond, e.g., only shooting); and the availability of live audio and text communications among players.

\section{Discussion}

Many aspects of political activism in games are observed to be heavily inspired by, if not copied from, everyday life activism, but some aspects appear novel, different, and original.

Tightly aligned with everyday life activism are many of its political causes, themes, and topics, such as national politics, international (often military) conflicts, and lifestyle choices. What moves people to become active in everyday life also moves them to become active in games. Games become another venue open to political activism. 
By direct import, media used in everyday political activism, such as songs, poetry, slogans, and posters, are also used in games. Also employed are ordinary life political symbols, such as flags.

Many forms and methods of dissemination of political views in games mirror corresponding forms in everyday life. Dyer-Witheford and de Peuter (2009, p. 204) describe "Save the Children selling virtual yaks for real money." Other examples described here include well-established practices, such as rallies and demonstrations, as well as DeLappe's appropriations of generic in-game communication channels for one-way transmissions of political messages.

The resemblance of in-game methods to those of everyday life also means that observations within and outside of games can match each other, and familiar patterns can be identified. For instance, it appears that people express mainstream political views more openly than niche positions, for example, in rallies rather than in anonymous image flashing.

However, political dissemination methods also differ between those of life and games. While the import of political actions and objects into games plays an important role in political expression, their role in the game world can be exclusively symbolic; they often have no mechanical effects in-game (e.g., virtual bomb explosions, power saws, and rifles). Unlike real-life political activism, few interventions (such as strategic blockades of in-game resources) actually affect players. The employment of mock terror attacks might be, in part, facilitated by the impossibility of actually hurting other players, that is, modifying the attributes of avatars or in-game objects or removing them. In-game protests appear to feature a relatively high level of humor (e.g., a burger shower for a Trump satire), possibly higher than in real-life events.

There are some political causes specific to games, such as in-game practices, policies, and rules. These are usually also the topics of in-game political expression. One specific theme which attracts considerable attention in some games is the players' political participation in and ownership of the game worlds.

Some methods of political expression in games appear to be original and inventive adaptions of well-known formats from everyday (political) life. For practical reasons, many everyday life demonstrations and rallies are limited to gathering, standing, walking, shouting, and showing signs. Through game mechanics, demonstrations and rallies in-game can easily go beyond these limitations. For instance, a long march across a game world, such as in WoW, is enabled by the avatars' in-game ability to quite tirelessly traverse long distances in comparatively short amounts of time. A sailing boat regatta is visible to other players and a viable expression of political protest in Second Life because avatar or camera movement is not restricted to solid ground, but includes flying and teleporting. DeLappe's worldwide sing-along performance, which uses the live audio communication mechanics ubiquitously available in games, appears to update the familiar (local) singing of protest songs. 
Special plays, such as pacifist, vegan, or speed runs, are quite common and popular in the gamer community. They have no precedent in everyday life political activism and are arguably an original combination of method and mechanics specific to digital games. While special plays such as pacifist runs can reflect a player's political position, it appears as if many special plays are driven by competitive challenge rather than political conviction and are probably not intended as in-game activism directed at other players (an investigation of shared or streamed online videos of plays is beyond the scope of this article). When players play games in specific ways (e.g., pacifist Warcraft) as a form of political expression, it appears to be a semi-private form of political expression; many plays are played offline or are, if online, practically invisible to other players. Special plays which often may represent a political position are plays with sexual orientations.

Some special plays are enabled if not invited by specific game mechanics. For instance, the non-lethal fighting mechanics in Undertale are taken to encourage pacifist plays; The Legend of Zelda: Breath of the Wild appears to specifically accommodate a vegan play style. The opposite position can also be observed: Special plays appear to be actually triggered by games whose mechanics oppose them (e.g., pacifist plays of violent FPS games).

If game mechanics are not of paramount importance in the decisions of activists as to which games to employ to transport their campaigns, other essential attributes or qualities are. Violent team-based competitive military-themed games (America's Army, Counter-Strike) are probably primarily used to mount political activism because they offer rather generic features, such as text chat and team speak. Many of the most commonly used games are also popular with, and widely played by, the target audience, and many of them are available at low or no cost. Poremba (2003) observes how a work such as Velvet-Strike "does not address the game community directly, but instead appeals to outside groups," that is, "to an external art/activist community" (ibid.). Some games are also chosen because the political message relates to them (e.g., political participation in Second Life) or protests something a game exemplifies (e.g., violence, war).

\section{Conclusion}

This project set out to investigate how mainstream, digital games are appropriated by players for political activism directed toward other players. The starting position was that cultural artefacts, such as games, are appropriated by their players, so the investigation did not focus on so-called political games. It is found that many aspects of political activism in games tightly align with aspects of everyday life activism, but some aspects appear novel, different, and original.

Copied from everyday life activism are many of its political causes, themes, and topics, such as national politics, international (often military) conflicts, and lifestyle choices (such as wearing fur, sexual orientation). By direct import, media used in everyday political 
activism, such as slogans, posters, songs, and poetry, are also used in games. Many forms and methods of dissemination of political views in games mirror corresponding forms in everyday life, such as rallies and demonstrations.

But, political dissemination methods also differ between life and games; the roles of actions and objects are often purely symbolic rather than effective (even more so than in everyday life). A considerable number of in-game political forms of expression appear to feature a rather high level of humor, possibly higher than in corresponding real-life events.

There are some political causes specific to games, such as in-game practices, policies, and rules (e.g., violence, and ownership of virtual worlds and access to them); these are usually also the topics of in-game political expression. Some methods of political expression in games appear to be original and inventive adaptions of well-known formats from everyday (political) life; for instance, demonstration formats can easily transgress well-established formats, such as standing, walking, and showing signs, and can include marches over long distances and sailing regattas. Special plays, such as pacifist and vegan runs, in which players decide to use only a certain subset of the available game features, appear to be an original feature of digital games; however, their use as political activism appears limited.

Game mechanics, which are highly relevant for in-game activism, include networked multiplayer play and the support of modding and persistent game worlds; also relevant are in-game communications and avatar and object skinning. These features are almost ubiquitously available in digital games. Mechanics specific to individual games or genres appear not to play a major role in the decisions of activists as to which games to employ to mount their activism. Usually, activists select game titles which offer gameplay and game content related to the political message (e.g., violent and militaristic FPS games). Other factors are popularity and availability in the target player community (for example Counter-Strike used as a platform by the activist mod Velvet-Strike).

\section{References}

ADLmostwanted (2007, 4 April). World of Warcraft white nationalist guild. Thread on Stormfront Canada. Retrieved from: https://www.stormfront.org/forum/t377747.

badash (2005, 7 April). Warcraft account suspended for "racial character naming." Post in thread on Stormfront Canada. Retrieved from: https://www.stormfront.org/forum/t196695.

BCSBuster (2013). Let's play Final Fantasy 7 - \#8: Cross-dressing cloud. Video on YouTube. Retrieved from: https://www.youtube.com/watch?v=Z-S7KNTfXwl.

Bogost, I. (2010). Persuasive games. The expressive power of videogames. Cambridge, MA: MIT Press.

Boluk, S., \& LeMieux, P. (2017). Metagaming: Playing, competing, spectating, cheating, trading, making, and breaking videogames. Minneapolis: University of Minnesota Press.

BootsandBracers (2007, 9 April). World of Warcraft white nationalist guild. Post in thread on Stormfront Canada. Retrieved from: https://www.stormfront.org/forum/t377747. 
cartmantul (2009a). Second Life hippo terror attack. Video on YouTube. Retrieved from: https://www. youtube.com/watch?v=_Dw-nQSTeQw.

cartmantul (2009b). Second Life Nazi attack. Video on YouTube. Retrieved from: https://www.youtube. com/watch?v=wWc1fp1wlvA.

ChronosPallas (2015). Minecraft apocalypse - S03E04 - "Political Posture." Video on YouTube. Retrieved from: https://www.youtube.com/watch?v=U1PleEHjXeU.

Cleptar (2016). Trump supporter in Second Life. Video on YouTube. Retrieved from: https://www.youtube. com/watch?v=hD7JrYjtC9c.

ComradeMikey (2017). A party political Minecraft on behalf of the Labour Party. Video on YouTube. Retrieved from: https://www.youtube.com/watch?v=giFkbgmJD9c.

Cool Gaming, Bros (2015). Dark Souls 2: A blind playthrough 11, "The Gender Bender." Video on YouTube. Retrieved from; https://www.youtube.com/watch?v=LCGt-TGe_dM.

Corentin (2005, 14 April). Warcraft account suspended for 'racial character naming." Post in thread on Stormfront Canada. Retrieved from: https://www.stormfront.org/forum/t196695.

Csskitty (2015). Gender bend Gerard way - Speed skin. Video on YouTube. Retrieved from: https://www. youtube.com/watch?v=s44fRye $6 \mathrm{mzg}$.

DeLappe, J. (2001). Howl: Elite Force Voyager online - Gaming performance. Video on YouTube. Retrieved from; https://www.youtube.com/watch?v=d4J9i6jQXUg (Jun 10-11, 2017).

DeLappe, J. (2007). dead-in-iraq. Video on YouTube. Retrieved from: https://www.youtube.com/ watch? $v=V T$ TnuUMM7frk.

DeLappe, J. (2010a). gg hootenanny! Gandhi's release party and global gaming singalong. Video on YouTube. Retrieved from: https://www.youtube.com/watch?v=e6hLz00SL_U.

DeLappe, J. (2010b). All you need is love gg hootenanny!.mov. Video on YouTube. Retrieved from: https:// www.youtube.com/watch? $v=a x E N n L f 3 i p g$.

DeLappe, J. (2011). Self portrait as monster truck. Video on YouTube. Retrieved from: https://www.youtube. com/watch?v=D0b6MXeHVol.

DeLappe, J. (2012). Quake/friends - performance art. Video on YouTube. Retrieved from: https://www. youtube.com/watch?v=A4dJFaGRVFk.

DeLappe, J. (2017a). Self portrait as monster truck: Joseph DeLappe. Retrieved from: www.delappe.net/ project/self-portrait-as-monster-truck.

DeLappe, J. (2017b). Howl: Elite Force Voyager online: Joseph DeLappe. Retrieved from: www.delappe.net/ play/howl-elite-force-voyager-online.

DeLappe, J. (2017c). Twitter torture/MGandhi in prison: Joseph DeLappe. Retrieved from: www.delappe. net/project/twitter-torturegandhi-in-prison.

DeLappe, J. (2017d). The great debates: Joseph DeLappe. Retrieved from: www.delappe.net/play/the-greatdebates.

DeLappe, J. (2017e). Quake/friends: Joseph DeLappe. Retrieved from: www.delappe.net/game-art/quakefriends.

Despres, D. (2007). Virtual Guantanamo. Video on YouTube. Retrieved from https://www.youtube.com/ watch?v=QT7p231Cfxk.

Dyer-Witheford, N., \& de Peuter, G. (2009). Games of empire: Global capitalism and video games. Minneapolis: University of Minnesota Press.

ediblefeet (2006). Reservoir fox - Second Life terror attack. Video on YouTube. Retrieved from: https:// www.youtube.com/watch? $v=23 \mathrm{C}$-tpfhcfU.

ediblefeet (2007). The end of Le Pen. Video on YouTube. Retrieved from: https://www.youtube.com/ watch? $v=X q V n A W \_I J 3 g$. 
Emillie (2016). NAZIS IN CLUB PENGUIN?! Video on YouTube. Retrieved from: https://www.youtube.com/ watch?v=HJpbwEtDh20.

Flanagan, M. (2009). Critical play: Radical game design. Cambridge, MA: MIT Press.

Galloway, A. R. (2006). Gaming: Essays on algorithmic culture. Minneapolis: University of Minnesota Press.

GiaNtakos (2008). Second Life: Solidarity for Greek protesters (R.I.P. Alexis Grigoropoulos). Video on YouTube. Retrieved from: https://www.youtube.com/watch?v=mBegf0y81aE.

gymnast86 (2017). Breath of the wild any\% speedrun in 41:59. Video on YouTube. Retrieved from: https:// www.youtube.com/watch?v=baJBYEKf60Y.

Hall, C. (2015, 25 June). Why is the developer of Rust assigning every male avatar a different penis size? (NSFW). Polygon. Retrieved from: https://www.polygon.com/2015/6/25/8841003/rust-penis-size-garrynewman-interview.

Hine, C. (2015). Ethnography for the internet: Embedded, embodied and everyday. London: Bloomsbury. idccom (2008). Anti-Israeli demonstration in Second Life. Video on YouTube. Retrieved from: https://www. youtube.com/watch?v=X8RClweJ9bl.

InfestedChris (2011). Insurgency Half-Life 2 mod. Video on YouTube. Retrieved from: https://www.youtube. com/watch?v=ILDaf5Ay4qU.

Israel, S. (2016, 18 April). Rust video game players outraged after half given female avatars. CBC News. Retrieved from www.cbc.ca/news/technology/rust-avatar-gender-race-assigned-1.3535949.

Johnson, L. (2016, 10 April). This game is forcing some players to be women, and they're freaking out. Motherboard. Retrieved from: https://motherboard.vice.com/en_us/article/d7y7jj/this-game-is-forcing-some-players-to-be-women-and-theyre-freaking-out.

Kersten-van Dijk, E.T., \& IJsselsteijn, W. A. (2016). Design beyond the numbers: Sharing, comparing, storytelling and the need for a quantified us. Interaction Design and Architecture(s) Journal - IxD\&A, (29), 121-135.

knightgraymon (2014). Gender bender DNA twister extreme yael part 1. Video on YouTube. Retrieved from: https://www.youtube.com/watch?v=h0BgmO6QG50.

Kotaku (2016). An anti-Trump rally in Second Life. Also an anti-perpendicular wizard ral. Video on YouTube. Retrieved from: https://www.youtube.com/watch?v=f9WFWxaYs8s.

Kotaku (2017). The Trump inauguration party in Second Life. Retrieved from: https://www.youtube.com/ watch?v=217cHaugGZ0.

Lees, J. (2006, 14 February). Valentine's Day in Azeroth. Engadget. Retrieved from: https://www.engadget. com/2006/02/14/valentines-day-in-azeroth.

Machinima (2008). Election Duel! Obama v. McCain - Who get's pwned? (World of Warcraft Machinima). Video on YouTube. Retrieved from: https://www.youtube.com/watch?v=h5Kg-K7em20.

mattr0x (2007). Protesting the ban on gambling in Second Life. Video on YouTube. Retrieved from: https:// www.youtube.com/watch?v=cE_5rD_4Smg.

McElroy, J. (2008, 16 October). Obama ads not just in Burnout Paradise. Engadget. Retrieved from: https:// www.engadget.com/2008/10/16/obama-ads-not-just-in-burnout-paradise.

McGamer, D. (2015). Fallout 4 sex change how to change gender. Video on YouTube. Retrieved from: https://www.youtube.com/watch?v=5OEzXNC47aU.

Nornsonur, H. (2012). The FurNation gamma incident. Video on YouTube. Retrieved from: https://www. youtube.com/watch?v=wwWlUVe0dGc.

Panganiban, R. (2011a). Anti-Mubarak demonstrations in Second Life (HD version). Video on YouTube. Retrieved from: https://www.youtube.com/watch?v=V2-DqVYcrao.

Panganiban, R. (2011b). Avatars against the war: A Second Life demonstration for peace. Video on YouTube. Retrieved from: https://www.youtube.com/watch?v=qaiGV_Hd0O8. 
PCLScripters (2008). Clubpenguin bots: Swastika bots. Video on YouTube. Retrieved from: https://www. youtube.com/watch?v=9cxrtAVbohg.

piercep (2006). The protest. Video on YouTube. Retrieved from: https://www.youtube.com/ watch?v=TfV1DrrY2r4.

PISTOLCm (2013). RON PAUL"S WORLD OF WARCRAFT MARCH TO FREEDOM. Video on YouTube. Retrieved from: https://www.youtube.com/watch?v=XDyheKhwWf8.

Poremba, C. (2003). Patches of peace: Tiny signs of agency in digital games. DiGRA International Conference: Level Up (n.p.).

rabidns (2005, 7 April). Warcraft account suspended for "racial character naming." Post in thread on Stormfront.org. Retrieved from: https://www.stormfront.org/forum/t196695.

Richard, G.T., \& Hoadley, C.M. (2013). Investigating a supportive online gaming community as a means of reducing stereotype threat vulnerability across gender. Proceedings of Games, Learning \& Society 9.0, 261-266.

RoxyPox (2012). Fem fortress - The consequences of gender-bending. Video on YouTube. Retrieved from: https://www.youtube.com/watch?v=8J1LfcrqhcQ.

Shaw, A. (2014). Gaming at the edge: Sexuality and gender at the margins of gamer culture. Minneapolis: University of Minnesota Press.

Sinclair, B. (2008, 16 October). Obama campaigns in Burnout, 17 other games. Game Spot. Retrieved from: https://www.gamespot.com/articles/obama-campaigns-in-burnout-17-other-games/1100-6199379.

Smith, G. (2014). Sims 3 gender change with cheats. Video on YouTube. Retrieved from: https://www.youtube.com/watch?v=ksOon4S3ImA.

Sundén, J., \& Sveningsson, M. (2013). Gender and sexuality in online game cultures: Passionate play. London: Routledge.

Swarm TV (2013). Fable 2 Episode 61: Gender Bender 5000. Video on YouTube. Retrieved from: https:// www.youtube.com/watch?v=Kta--dU0BP4.

Taylor, T.L. (2006). Play between worlds: Exploring online game culture. Cambridge, MA: MIT Press.

theDeModcracy (2016). Dark Souls 3 speedrun in 1:16.44 (all bosses) with walkthrough commentary. 2016. Video on YouTube. Retrieved from: https://www.youtube.com/watch?v=z0izRQ2p7bs.

TheSims2MovieGirl1 (2012). Gender bender The Sims 2. Video on YouTube. Retrieved from: https://www. youtube.com/watch?v=-qRGhwD-UFs.

Thompson, N.J.A. (2014). Queer/ing game space: Sexual play in the World of Warcraft. Media Fields Journal, 8. Retrieved from: www.mediafieldsjournal.org/queering-game-space/2014/5/30/queering-gamespace-sexual-play-in-world-of-warcraft.html.

TiffyKishman (unknown). Tiffy's Second Life; Trump rally place. Video on YouTube. Retrieved from: https:// www.youtube.com/watch?v=jlrck34pEFc.

Weebhut Jr (2017). The Legend of Zelda: Breath of the Wild | Part 1 | VEGAN PLAYTHROUGH!! Video on YouTube. Retrieved from: https://www.youtube.com/watch?v=u-b3py7vUpk.

Weird_Stealth. This Spartan Life Episode 1 Module 1. 2006. Retrieved from: https://www.youtube.com/ watch? $v=r C D Y w \cup 0 C X 2 Q$.

wew lad (2017). NAKED + VEGAN ZELDA: Breath of the Wild LIVE| | No Armor or Meat Run [Part 1]. Video on YouTube. Retrieved from: https://www.youtube.com/watch?v=pwnddQW9vHI.

White, M. (2008). Second Life protest regatta (2008). Video on YouTube. Retrieved from: https://www. youtube.com/watch?v=duM2ttpqT5Q.

White Youth (2005, 7 April). Warcraft account suspended for "racial character naming." Post in thread on Stormfront Canada. Retrieved from: https://www.stormfront.org/forum/t196695.

Wikipedia (2017). Club Penguin. Retrieved from: https://en.wikipedia.org/wiki/Club_Penguin. 
WoWProgress.com (2017a).WoW Guild Fascist Pigs @ Illidan :: WoWProgress - World of Warcraft Rankings. Retrieved from: https://www.wowprogress.com/guild/us/illidan/Fascist+Pigs.

WoWProgress.com (2017b). WoW Guild Fascist Duelists @ Illidan :: WoWProgress - World of Warcraft Rankings. Retrieved from: https://www.wowprogress.com/guild/us/illidan/Fascist+Duelists.

xxyxs (2008). World of Warcraft Ron Paul march! Video on YouTube. Retrieved from: https://www.youtube.com/watch?v=4szfw73b-IY.

XYZ Exhibition (2002). Velvet-Strike. Video on YouTube. Retrieved from: https://www.youtube.com/ watch?v=12z_J7KNs81.

Zakalwe, C. (2011, 31 July). Breivik's World of Warcraft History. Islam versus Europe. Retrieved from: islamversuseurope.blogspot.dk/2011/07/breiviks-world-of-warcraft-history.html.

zero696696 (2008). Ron Paul WoW rally. Video on YouTube. Retrieved from: https://www.youtube.com/ watch?v=w)BucpgzHvU.

Zerxes (2012, 9 April). Any radical leftist political guild? Post in thread on Stormfront Canada. Retrieved from: https://us.battle.net/forums/en/wow/topic/4362521063.

\section{Endnotes}

1 Other possible venues of investigation include Vimeo, Twitter, Twitch, Reddit, Flickr, and Instagram. Future work might include embedding with in-game political activists and interviewing players.

2 The in-game radio (Dyer-Witheford \& de Peuter, 2009, pp. 179f.), specifically the right wing WKTT station in GTA 4, and the in-game cartoon series Republican Space Rangers (ibid., p. 180) in GTA 4 (2008) and GTA 5 (2013) are, thus, ignored.

3 For instance, if "crafting an item" is part of the expected play of a game, it would be seen as "a permissible action" that "instantiate[s] the agency of the primary author," rather than that of the player (Poremba, 2003).

4 While widely regarded as a political game, the game's author claims that there is no political message behind it.

5 Mods for commercial titles are included in this investigation when they modify or subvert the original games (e.g., the Velvet-Strike mod for Counter-Strike), not when they create completely new ones (total conversion mods, e.g., the Insurgency mod for Half-Life 2).

6 It is debatable if Second Life is a game, but it is included here because it is likely that, to a certain degree, in Second Life, similar messages are propagated, methods used, and mechanics employed as in (proper) games.

7 Performances and disruptive events, and demonstrations and rallies could be seen as (procedural) gamification (Bogost, 2010), while re-creation of locations and the showing of signs could be seen as representational gamification.

8 After its release in 2013, players' avatars in the multiplayer online survival game Rust were randomly assigned races, facial features, hair color, and penis sizes (Hall, 2015), and, finally, in 2016, half the avatars were made female (Johnson, 2016), "with no option to change genders" (Israel, 2016). The avatar settings are permanently tied to players" Steam IDs (Hall, 2015). While there was "clearly not a mass exodus to penis-only pastures" (Johnson, 2016), the backlash in social media, such as Reddit, appears to have been considerable, including "threats, harassment and insults" (moderator Foamed qtd. in ibid.). One player comments (qtd. in ibid.), "Please let me change my gender because i don't wanna be a FUCKING WOMEN for the rest of my life on rust." 
Article: On political activism in digital games

Daniel Cermak-Sassenrath Associate Professor Center for Computer Games Research

ITU, Copenhagen dace@itu.dk 